\section{Compressive strength and Scheffe's optimization of mechanical properties of recycled ceramics tile aggregate concrete}

Edidiong E. AMBROSE - Department of Civil Engineering, Akwa Ibom State University, Ikot Akpaden, Akwa Ibom State, Nigeria - edidiongambrose@aksu.edu.ng

FIDELIS O. OKAFOR - Department of Civil Engineering, University of Nigeria, Nsukka, Nigeria - fidelis.okafor@unn.edu.ng

MichaEl E. ONYIA - Department of Civil Engineering, University of Nigeria, Nsukka, Nigeria - michael.onyia@unn.edu.ng

Érkezett: 2020. 10. 18. - Received: 18. 10. 2021. " https://doi.org/10.14382/epitoanyag-jsbcm.2021.14

\section{Abstract}

Ceramic industry generates a large amount of wastes which are presently not reused in any significant quantity. Reusing these wastes in concrete could solve the ceramic industry waste management problem and also lead to a more sustainable concrete industry. While the use of ceramic wastes as coarse aggregate has been extensively investigated, not much findings are available on its use as fine aggregate and there are presently no models for predicting the properties of ceramic wastes aggregate concretes. This study investigates effect of crushed recycled-ceramic tiles (CRT) fine aggregate content on compressive strength of concrete. Scheffe's second degree polynomial models were also formulated for compressive strength, slump height and cost of CRT concrete. Results show that incorporation of CRT as fine aggregate improves the compressive strength of concrete and this increase is directly proportional to its content. Authors therefore recommend up to $100 \%$ replacement of conventional fine aggregate with CRT in concrete production. The formulated models could predict compressive strength, slump and cost of CRT concrete if the mix ratio is known and vice versa. Analysis of variance and normal probability plots of model residuals were used to test adequacy of the models, and the models were found to be adequate at $95 \%$ confidence level. With the model equations, sample optimization was carried out to obtain the most economical mix for certain predefined criteria and the results were promising. Several similar optimizations can be carried out using the formulated model equations for any desired criteria of the modeled responses.

Keywords: compressive strength, concrete, optimization, recycled ceramic waste, Scheffe's theory, slump Kulcsszavak: nyomószilárdság, beton, optimalizálás, újrahasznosított kerámia hulladék, Scheffe elmélet, roskadás
Ph.D student at Department of Civil Engineering, University of Nigeria, Nsukka, Nigeria.

Lecturer at Akwa Ibom State University, Ikot Akpaden, Akwa lbom State, Nigeria. Registered Engineer at Council for the Regulation of Engineering in Nigeria (COREN). Member, Nigerian Society of Engineers. Research Interests include: recycled aggregate concrete, durability of cement-based materials, modelling

Fidelis 0. OKAFOR Professor of highway and construction materials at University of Nigeria, Nsukka, Nigeria. Registered Engineer at Council for the Regulation of Engineering in Nigeria (COREN). Member, Nigerian Society of Engineers. Research Interests include: soil, cement and concrete materials.

Michael E. ONYIA Ph.D (Civil Engineering). Senior Lecturer at the Department of Civil Engineering at the University of Nigeria, Nsukka, Nigeria. Registered Engineer at Council for the Regulation of Engineering in Nigeria (COREN). Member, Nigerian Society of Engineers. Research Interests include: structures, soil, cement and concrete materials.

\section{Introduction}

Concrete has remained the most versatile and sustainable construction material all over the world. As a result, its demand is ever increasing. It is estimated that over 33 billion tonnes of concrete is consumed annually [1], making it the most widely used construction materials [2], the most consumed manufactured material and the second most consumed material after water [3]. One major advantage of the use of concrete is that its constituents - basically Portland cement, aggregate and water - can almost always be locally sourced. However, the sourcing of these materials is ecologically harmful. For instance, the manufacture of one tonne of Portland cement generates about one tonne of $\mathrm{CO}_{2}$ into the atmosphere $[4,5,6]$, accounting for about $5 \%$ of global $\mathrm{CO}_{2}$ emission $[6,7]$. There is also a rapid depletion in the natural reserves of conventional crushed rock aggregate and natural river sand. All these threaten the sustainability of concrete as a construction material.

As a way out, the use of secondary cementitious materials like fly ash, metakaolin and silica fumes as partial replacement for cement in concrete production has become rampant. There have also been attempts to either partially or totally replace the conventional aggregates in concrete production. Materials like recycled aggregate, polystyrene aggregate [8], laterite and quarry dust [9], etc. have been used. A good number of these replacement materials are industrial wastes or by-products. Of recent, there has been a growing number of researches on the use of ceramic wastes as aggregate in concrete production and the results have been promising. Ceramic wastes are industrial waste products from the manufacturing of sanitary wares, earthen wares, ceramic tiles, bricks, electrical insulators, etc. Some of these wastes are as a result of cracks, glazing faults, production error, off-standard products, size discrepancy, production error, etc. [10]. A considerable amount of ceramic wastes is also generated during transportation and distribution while the greatest percentage comes as construction and demolition wastes. These sum up to millions of tonnes of ceramic wastes generated annually and disposed as landfills all over the world $[11,12]$. As at present, ceramic waste is not recycled in any significant quantity $[10,11,12]$ and it is classified as non- 
biodegradable $[12,13]$. Hence, its incorporation into concrete production will be a win-win situation to both the construction and ceramics industries. Moreover, ceramic wastes possess qualities expected to improve concrete properties. They are durable and hard with high resistance to physical, chemical and biological degradation $[14,15,16]$. They are pozzolanic with low density and high resistance to abrasion $[10,13]$.

Investigation on incorporation of ceramic wastes into concrete production is a novel line of research at international level. Most of the researches are on the use of ceramic wastes as aggregate and mostly as coarse aggregate with very few on its use as fine aggregate. Medina et al. [17] carried out extensive studies on strength properties of concrete with partial replacement of conventional coarse aggregate with ceramic sanitary ware waste aggregate and reported that the resulting concrete performs better than conventional concrete in terms of mechanical strengths and that these properties increase as the percentage of ceramic wastes aggregate increases. This result was in line with several other findings on ceramic sanitary ware waste aggregate concrete $[18,19]$ and those using other ceramic wastes as coarse aggregate $[16,20,21]$. These improved mechanical performances are attributed to the characteristics of ceramic waste aggregate - relatively high strength, irregular shape and rough surface texture - which enhance aggregate/cement paste bonding; and the refined pore system of the resulting concrete [23]. The few researches on use of recycled ceramic wastes as fine aggregate have also reported comparable or improved results. Alves et al. [24] reported that compressive strength does not seem to be significantly affected by incorporation of fine recycled brick aggregate when compared with conventional concrete. This was similar to the result of Aliabdo et al. [25] which showed that compressive strength remains the same or slightly improves as percentage of replacement with recycled bricks aggregate increases. Torkittikul and Chaipanich [14] observed that compressive strength of ceramic waste concrete increased with ceramic waste content and was optimum at $50 \%$ replacement; dropping when the ceramic waste content increased beyond 50\%. This drop was however linked to workability problem posed by inclusion of ceramic waste aggregate. Comparable compressive strength was also reported by Elci with complete replacement of fine aggregate with recycled floor tile waste [10].

Concrete properties at both fresh and hardened state are to a great extent - determined by the proportions of the mix constituents. As such concrete mix design is of paramount important to concrete users and concrete mix optimization is of even more importance. The later involves careful selection and proportioning of concrete constituents to achieve the desired concrete properties at optimum point, usually at minimum cost. This was traditionally achieved through trial mixes on a trial and error bases [26, 27]. The traditional method has proved to be inefficient and could be very tedious and complex especially when dealing with concrete with many constituents. The use of statistical experimental design methodology is far more efficient and economical. In this approach, a set of trial batches is employed in any chosen statistically established procedure [27]. These mixes cover a chosen range of proportions for each concrete constituent.
Statistical methods usually involve fitting empirical models to experimental data for each performance criterion. The resulting model equations are usually algebraic functions of individual component proportions which may include cement content, water/cement ratio, aggregate content, percentage of cement or aggregate replacement etc. as independent variables, while the required concrete properties like strength, slump, cost etc. are the dependent variables. With these equations, concrete mix optimization can easily be achieved with limited or no trial mix. In general, the process of optimizing a response using a collection of mathematical and statistical techniques for empirical model building is termed response surface methodology (RSM). RSM involves three major steps which are [25]: (1) design of experiment, (2) formulation of model equations, and (3) optimization of the equations under certain given constraints. Design of experiment (DoE) determines points where the desired responses should be evaluated; thereby establishing relationships between a number of independent variables and the responses. It allows multiple input factors to be manipulated simultaneously to determine their combined effects on the desired responses. The two major approaches to design of experiment are factorial method and mixture experiment $[26,27]$ and one of the first and most popular type of mixture experiment is the simplex-lattice design [28].

There are presently no such mathematical models for ceramic waste aggregate concrete and the need for such is imminent. This study aims to further investigate the feasibility of incorporating recycled ceramic waste tiles as fine aggregate in concrete production by studying the effect of ceramic tile waste aggregate content on compressive strength. Mathematical models are also formulated using Scheffe's simplex lattice theory, for predicting and optimization of compressive strength, slump height and cost of concrete with partial or full replacement of river sand with ceramic tile waste fine aggregates.

\subsection{Simplex lattice design}

Simplex lattice design is a form of mixture experiment which is a general technique for modelling response and components relationships. Mixture experiment techniques are mainly for cases where the response depends on the mass or volume proportions of individual components and not on their total mass or volume [29-32] and this is typical of concrete properties. If $q$ denotes the number of mixture components, $X_{1}, X_{2}, X_{3}, \ldots X_{q}$, and the desired response is denoted by $y$, then for a $q$-component mixture,

$y=F\left(X_{1}, X_{2}, X_{3}, \ldots \ldots \ldots, X_{q}\right)$

For mixture experiments, no component should have a negative value and the sum of the component proportions must be equal to one. Mathematically these can be represented as:

$$
\begin{aligned}
& X_{1}+X_{2}+\ldots+X_{q}=\sum_{i=1}^{q} X_{i}=1 \\
& 0 \leq X_{i} \leq 1
\end{aligned}
$$

Since the sum of component proportions (variables) is constrained to unity, it therefore follows that only (q-1) of the variables can be independently chosen. Hence, from Eq. (2), 
$X_{q}=1-\sum_{i=1}^{q-1} X_{i}$

\subsubsection{Factor space in simplex lattice design}

A lattice is an ordered and regular patterned distribution of points. In a $q$-component mixture experiment, the factor space is a regular $(q-1)$ simplex and the relationships in Eqs. (1) to (4) holds $[30,32]$. If $q=2$, we have the lattice simplex as a straight line, for $q=3$, it is an equilateral triangle while for $q$ $=4$, the simplex will be a regular tetrahedron with each vertex representing each of the components. As a result of Scheffe's theory, simplex lattice designs are simply referred to as Scheffe's simplex lattice design. Scheffe proposed that each component of the mixture in a mixture design resides on a vertex of a simplex lattice with $(q-1)$ factor space such that if the degree of the polynomial to be fitted to the design is denoted by $n$, then a $\{q, n\}$ simplex lattice for $q$-components consists of uniformly spaced points defined by all the possible combinations of $(n+1)$ levels of each component [33].

Properties of concrete depend on the adequate mass or volume proportioning of its constituents and not on its total mass or volume. Therefore, Scheffe's optimization theory can be used to model and optimize concrete properties. Scheffe introduced polynomial regression to model responses. The general form of the polynomial equation of degree $n$ in a $q$-component mixture is given as:

$\hat{\mathrm{y}}=\mathrm{b}_{0}+\sum_{1 \leq i \leq q} b_{i} X_{i}+\sum_{1 \leq i \leq j \leq q} b_{i j} X_{i} X_{j}+\sum_{1 \leq i \leq j \leq k \leq q} b_{i j k} X_{i} X_{j} X_{k}+\ldots$

$+\sum b_{i_{1} i_{2 \ldots i}} X_{i_{1}} X_{1_{2}} X_{i_{n}}$

\subsubsection{Scheffe's reduced polynomial}

The number of terms in Eq. (5) is given as $C_{n}^{q+n}$. This is also the minimum number of design points required to determine coefficients of the resulting model. However, by substituting Eq. (2) into (5), the number of terms in the polynomial can be reduced to:

$N=C_{n}^{q+n-1}=\frac{(q+n-1) !}{(q-1) !(n) !}$

For a 5-compomponent mixture adopted in this work, the reduced second-degree polynomial can be obtained as follows [30 - 32, 34, 35]:

From Eq. (5),

$$
\begin{aligned}
\hat{y} & =\mathrm{b}_{0}+b_{1} X_{1}+b_{2} X_{2}+b_{3} X_{3}+b_{4} X_{4}+b_{5} X_{5}+b_{12} X_{1} X_{2}+b_{13} X_{1} X_{3} \\
& +b_{14} X_{1} X_{4}+b_{15} X_{1} X_{5}+b_{23} X_{2} X_{3}+b_{24} X_{2} X_{4}+b_{25} X_{2} X_{5}+b_{34} X_{3} X_{4} \\
& +b_{35} X_{3} X_{5}+b_{45} X_{4} X_{5}+b_{11} X_{1}^{2}+b_{22} X_{2}^{2}+b_{33} X_{3}^{2}+b_{44} X_{4}^{2}+b_{55} X_{5}^{2}
\end{aligned}
$$

Recall from Eq. (2) that

$X_{1}+X_{2}+X_{3}+X_{4}+X_{5}=1$

Multiplying $E q$. (8) by $b_{0}$ gives

$b_{o}\left(X_{1}+X_{2}+X_{3}+X_{4}+X_{5}\right)=b_{o}$

Multiplying Eq. (8) by $X_{1}, X_{2}, X_{3}, X_{4}$ and $X_{5}$ in succession and rearranging the terms gives:
$X_{1}^{2}=X_{1}-X_{1} X_{2}-X_{1} X_{3}-X_{1} X_{4}-X_{1} X_{5}$

$X_{2}^{2}=X_{2}-X_{1} X_{2}-X_{2} X_{3}-X_{2} X_{4}-X_{2} X_{5}$

$X_{3}^{2}=X_{3}-X_{1} X_{3}-X_{2} X_{3}-X_{3} X_{4}-X_{3} X_{5}$

$X_{4}^{2}=X_{4}-X_{1} X_{4}-X_{2} X_{4}-X_{3} X_{4}-X_{4} X_{5}$

$X_{5}^{2}=X_{4}-X_{1} X_{5}-X_{2} X_{5}-X_{3} X_{5}-X_{4} X_{5}$

Substituting Eqs (9) and (10) into Eq. (7) and simplifying the terms gives:

$\begin{aligned} \hat{y} & =\left(b_{12}-b_{11}-b_{22}\right) X_{1} X_{2}+\left(b_{13}-b_{11}-b_{33}\right) X_{1} X_{3}+\left(b_{14}-b_{11}-b_{44}\right) X_{1} X_{4} \\ & +\left(b_{14}-b_{11}-b_{55}\right) X_{1} X_{5}+\left(b_{23}-b_{22}-b_{33}\right) X_{2} X_{3}+\left(b_{24}-b_{22}-b_{44}\right) X_{2} X_{4} \\ & +\left(b_{25}-b_{22}-b_{55}\right) X_{2} X_{5}+\left(b_{34}-b_{33}-b_{44}\right) X_{3} X_{4}+\left(b_{35}-b_{33}-b_{55}\right) X_{3} X_{5} \\ & +\left(b_{45}-b_{44}-b_{55}\right) X_{4} X_{5}+\left(b_{0}+b_{1}+b_{11}\right) X_{1}+\left(b_{0}+b_{2}+b_{22}\right) X_{2} \\ & +\left(b_{0}+b_{3}+b_{33}\right) X_{3}+\left(b_{0}+b_{4}+b_{44}\right) X_{4}+\left(b_{0}+b_{5}+b_{55}\right) X_{5}\end{aligned}$

If we denote $\beta_{i}=b_{0}+b_{i}+b_{i i}$ and $\beta_{i j}=b_{i j}-b_{i i}-b_{j j}$

Eq. (11) then becomes:

$$
\begin{aligned}
\hat{y} & =\beta_{1} X_{1}+\beta_{2} X_{2}+\beta_{3} X_{3}+\beta_{4} X_{4}+\beta_{5} X_{5}+\beta_{12} X_{1} X_{2}+\beta_{13} X_{1} X_{3} \\
& +\beta_{14} X_{1} X_{4}+\beta_{15} X_{1} X_{5}+\beta_{23} X_{2} X_{3}+\beta_{24} X_{2} X_{4}+\beta_{25} X_{2} X_{5}+\beta_{34} X_{3} X_{4} \\
& +\beta_{35} X_{3} X_{5}+\beta_{45} X_{4} X_{5}
\end{aligned}
$$

Eq. (13) is the reduced second-degree polynomial for a 5 -component mixture and the number of terms is 15 according to Eq. (6) as against 21. The reduced polynomial is generally referred to as conical polynomial or $\{q, n\}$ polynomial and its general form is given as:

$$
\begin{aligned}
& \text { For linear }(n=1) ; \hat{y}=\sum_{1 \leq i \leq q} \beta_{i} X_{i} \\
& \text { For quadratic }(n=2) ; \hat{y}=\sum_{1 \leq i \leq q} \beta_{i} X_{i}+\sum_{1 \leq i \leq j \leq q} \beta_{i j} X_{i} X_{j}
\end{aligned}
$$

\subsubsection{Interaction of components in Scheffe's factor space}

In Scheffe's simplex design, the mixture components are evenly distributed in the simplex. The proportions assumed by each component is $n+1$ equally spaced level from 0 to 1 based on Eq. (16).

$X_{i}=0, \frac{1}{n}, \frac{2}{n}, \ldots .1$

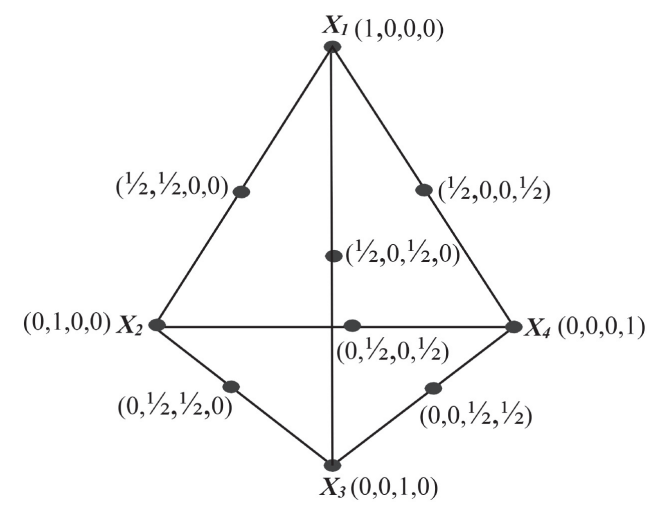

Fig. $1 A\{4.2\}$ Scheffe's simplex lattice showing pseudo ratios at design point

1. ábra A $\{4.2\}$ Scheffe szimplex rács, amely a pszeudó-arányokat mutatja a egyes tervezési pontokon

Thus, for a second-degree polynomial simplex design $(n=2)$, each component must take the levels: 0 , and 1 while for a cubic polynomial $(\mathrm{n}=3)$, the levels are: 0 , and 1 . Consider a $\{4,2\}$ 
simplex lattice as in Fig. 1. The factor space is a tetrahedron and each component assumes the proportions 0 , and 1 . There are ten points at the boundaries and vertices of the tetrahedron corresponding to the number of terms in the reduced seconddegree polynomial in $E q$. (15). At the vertices, the four points defined by $(1,0,0,0) ;(0,1,0,0) ;(0,0,1,0)$ and $(0,0,0,1)$ represent single component mixtures while the remaining six points each at the middle of each of the edges represent binary blends of two component mixtures.

\subsubsection{Determination of coefficients of Scheffe's} polynomial

There is a relationship between design points on Scheffe's lattice simplex and number of terms in the reduced polynomial in Eqs. (13), (14) and (15). Thus, the coefficients of the equations can be expressed as functions of expected responses $\left(y_{i}\right)$ at the design and control points of the simplex. The general relationship between the two is given as:

$\beta_{i}=y_{i}$ and $\beta_{i j}=4 y_{i j}-2 y_{i}-2 y_{j}$

\subsection{Augmented simplex lattice design}

Simplex lattice design contains design points only at the vertices and edges of the simplex and contains just the necessary design points needed to formulate the model equations. As such, it is a saturated design $[32,35]$. It does not give any information about the inside of the simplex. To augment simplex design, it is sometimes necessary to incorporate additional points within the inside of the simplex [26]. These additional points in addition to improving the simplex deign also help in testing the adequacy of the fitted model; hence they are also referred to as check points. According to Anya [26], the common practice is to augment the simplex by selecting design points at the centroid and at midway between the centroid and each of the vertices. Augmented simplex design still maintains the model equation form as that of simplex lattice design. However, estimated model coefficients differ slightly from those obtained using only simplex lattice design points.

\section{Materials and methods}

Investigation in this study was in two phases. In the first phase (Phase A), compressive strength of concrete with different replacement levels of conventional fine aggregate with Crushed Recycled-ceramic Tiles (CRT) was studied. In the second phase (Phase B), polynomial models were developed using Scheffe's simplex lattice theory for predicting and optimization of compressive strength, slump and cost of concrete incorporating CRT as fine aggregate.

\subsection{Materials}

Materials used for laboratory experiments in both phases of this work were cement, water, river sand (RS), CRT and granite chippings. Cement and water served as binder, while river sand and CRT served as fine aggregates (FA) and granite chippings was used as Coarse Aggregates (CA). Unicem brand of Portland Limestone cement (Strength class 32.5R) conforming to NIS 444-1 [36] was used. The river sand was obtained from a river sand mining site at Ikot Ekong, Akwa Ibom State while granite chippings used was from a quarry in Akamkpa, Cross River State all in Nigeria. CRT used were floor and wall tiles that had passed through complete manufacturing process but were either cracked or broken during transportation and distribution process. They were obtained from a dealer in Uyo, broken into smaller pieces and crushed into the required size using a mechanical mill. Particle size distributions of fine aggregates and coarse aggregate used are shown in Table 1 and Table 2 respectively, while specific gravities and bulk densities of all the aggregates are shown in Table 3 and chemical composition of cement and CRT are presented in Table 4.

\begin{tabular}{lllllllllll}
\multicolumn{2}{c}{$\begin{array}{c}\text { Sieve Size } \\
(\mathrm{mm})\end{array}$} & 3.35 & $\mathbf{1 . 7 0}$ & $\mathbf{0 . 8 5}$ & $\mathbf{0 . 4 2 5}$ & $\mathbf{0 . 3 0 0}$ & $\mathbf{0 . 2 1 2}$ & $\mathbf{0 . 0 7 5}$ & Pan \\
\hline $\begin{array}{l}\text { \% } \\
\text { Passing }\end{array}$ & Sand & 98.00 & 92.00 & 74.40 & 36.80 & 18.40 & 6.40 & 2.00 & 0.00 \\
\cline { 2 - 9 } & CRT & 87.00 & 60.20 & 38.80 & 25.20 & 20.60 & 15.40 & 7.60 & 0.00
\end{tabular}

Table 1 Particle size distribution for sand and CRT

1. táblázat A homok és a CRT szemcseméret-eloszlása

$\begin{array}{llllllllll}\begin{array}{c}\text { Sieve Size } \\ (\mathrm{mm})\end{array} & 28 & 20 & 13.2 & 13 & 10 & \mathbf{8} & \mathbf{6 . 7} & \text { pan } \\ \text { \% Passing } & 100 & 99.6 & 81.7 & 80.3 & 43.6 & 26.1 & 7.0 & 0.0 \\ & \\ \text { Table 2 } & \text { Particle size distribution for CA } & & & & & \\ \text { 2. táblázat } & \text { A CA szemcseméret-eloszlása }\end{array}$

\begin{tabular}{lccc}
\multicolumn{1}{c}{ Property } & Sand & CRT & CA \\
\hline Specific gravity & 2.61 & 2.40 & 2.39 \\
\hline Bulk density $\left(\mathbf{k g} / \mathbf{m}^{3}\right)$ & 1635 & 1373 & 1386
\end{tabular}

Table 3 Physical properties of aggregates

3. táblázat Az adalékanyagok fizikai tulajdonságai

\begin{tabular}{|c|c|c|}
\hline \multirow{2}{*}{ Compound } & \multicolumn{2}{|c|}{$\%$ composition by mass } \\
\hline & Cement & CRT \\
\hline Iron Oxide $\left(\mathrm{Fe}_{2} \mathrm{O}_{3}\right)$ & 2.25 & 3.07 \\
\hline Aluminum Oxide $\left(\mathrm{Al}_{2} \mathrm{O}_{3}\right)$ & 4.73 & 17.50 \\
\hline Silicon dioxide $\left(\mathrm{SiO}_{2}\right)$ & 19.84 & 66.13 \\
\hline Calcium Oxide (CaO) & 70.32 & 5.70 \\
\hline Manganese Oxide (MnO) & 0.01 & 0.58 \\
\hline Magnesium Oxide (Mg0) & 1.47 & 2.14 \\
\hline Zinc Oxide (ZnO) & & 0.42 \\
\hline Sulfur trioxide $\left(\mathrm{SO}_{3}\right)$ & 0.03 & - \\
\hline Sodium Oxide $\left(\mathrm{Na}_{2} \mathrm{O}\right)$ & 0.08 & 0.09 \\
\hline Potassium Oxide $\left(\mathrm{K}_{2} \mathrm{O}\right)$ & 0.72 & 1.02 \\
\hline LOI (Loss of Ignition) & 1.01 & 3.30 \\
\hline
\end{tabular}

Table 4 Chemical composition of cement and CRT

4. táblázat A cement és a CRT kémiai összetétele

\subsection{Mix proportion for phase A}

In this phase, 12 different mixes were used based on the four mix proportions in Table 5. The mix proportions in Table 5 
were designated A, B, C and D respectively. For each of them, the fine aggregate portions were obtained by combining sand and CRT with CRT content ranging from 0 to $100 \%$ with a step of $50 \%$. Hence, for each mix proportion, three different mixes were obtained with percentage replacement of sand with CRT of $0 \%, 50 \%$ and $100 \%$.

\subsection{Design of experiment for Phase B}

In the second phase of this study which involved modelling, number of design components was five and the data would be fitted into Scheffe's second-degree polynomial. Therefore, the mixture experiment was designed using augmented $\{5,2\}$ simplex lattice with the aid of a commercial statistical software, Minitab 16 and the design matrix is presented in Table 6. There were 21 design points and 27 runs. The 21 design points included 15 design points from Eq. (6), the centroid and five axial points. Six design points (the five vertices and centroid) were replicated and the runs were randomized. From Eqs (2) and (3), the lower and upper boundaries for each component were 0 and 1 respectively while the sum of all components for each run equals unity. From the design matrix, the five replicated runs that represent the five mixes at the vertices of the simplex were: Run Orders 10 and 22 (Vertex $\mathrm{X}_{1}$ ), 3 and 4 (Vertex $\mathrm{X}_{2}$ ), 11 and 18 (Vertex $\left.\mathrm{X}_{3}\right), 6$ and $12\left(\right.$ Vertex $\left.\mathrm{X}_{4}\right)$, then 8 and $13\left(\right.$ Vertex $\left.X_{5}\right)$. The results at these vertices would define the bound of the simplex and the resulting models.

\begin{tabular}{lcccc}
\multicolumn{1}{c}{ Components } & A & B & C & D \\
Cem II 32.5 (kg) & 325 & 406 & 418.3 & 553.5 \\
\hline $\begin{array}{l}\text { Fine Aggregate (kg) } \\
\text { (Sand + CRT) }\end{array}$ & 650 & 609 & 627.5 & 553.5 \\
\hline Coarse Aggregate (kg) & 1300 & 1218 & 1255 & 1107 \\
\hline Water (kg) & 195 & 243.5 & 209 & 249 \\
\hline w/c & 0.6 & 0.6 & 0.5 & 0.45
\end{tabular}

Table 5 Mix proportions per cubic meter of concrete for phase A

5. táblázat Az A fázis során használt beton keverék összetétele köbméterenként

\subsubsection{Pseudo components and actual components}

The relationship between pseudo components and real components is expressed in Eq. (18) where $Z$ is a column matrix of real component ratios and $\boldsymbol{X}$ is a column matrix of the pseudo components at each run. $A$ is a square matrix of actual mix (real components) corresponding to the pure blends at the five vertices of the simplex. These mixes were selected by the researchers through experience and a series of trial mixes.

$Z=A X$

The mix ratios at the respective vertices that formed the matrix $\boldsymbol{A}$ were as follows:

At Vertex $X_{1}$, we have the ratios of water $\left(Z_{1}\right)$, cement $\left(Z_{2}\right)$, sand $\left(Z_{3}\right)$, CRT $\left(Z_{4}\right)$ and CA $\left(Z_{5}\right)$ respectively as: $[0.6: 1: 0$ : $1.5: 3]$. At the other four vertices we have $[0.5: 1: 1.5: 0 ; 3]$, $[0.65: 1: 2.5: 0: 4.5],[0.4: 1: 1: 0: 2]$ and $[0.45: 1: 0: 1: 2]$ respectively. Putting these into a matrix form we have:

$A=\left(\begin{array}{ccccc}0.6 & 0.5 & 0.65 & 0.4 & 0.45 \\ 1 & 1 & 1 & 1 & 1 \\ 0 & 1.5 & 2.5 & 1 & 0 \\ 1.5 & 0 & 0 & 0 & 1 \\ 3 & 3 & 4.5 & 2 & 2\end{array}\right)$

and substituting into Eq. (18), we now have

$\left(\begin{array}{l}Z_{1} \\ Z_{2} \\ Z_{3} \\ Z_{4} \\ Z_{5}\end{array}\right)=\left(\begin{array}{ccccc}0.6 & 0.5 & 0.65 & 0.4 & 0.45 \\ 1 & 1 & 1 & 1 & 1 \\ 0 & 1.5 & 2.5 & 1 & 0 \\ 1.5 & 0 & 0 & 0 & 1 \\ 3 & 3 & 4.5 & 2 & 2\end{array}\right)\left(\begin{array}{c}X_{1} \\ X_{2} \\ X_{3} \\ X_{4} \\ X_{5}\end{array}\right)$

Eq. (19) was used to compute components in real ratios that was used for sample preparation in Phase B. The computation was as follows:

At Run Order 1;

$\left(\begin{array}{l}Z_{1} \\ Z_{2} \\ Z_{3} \\ Z_{4} \\ Z_{5}\end{array}\right)=\left(\begin{array}{ccccc}0.6 & 0.5 & 0.65 & 0.4 & 0.45 \\ 1 & 1 & 1 & 1 & 1 \\ 0 & 1.5 & 2.5 & 1 & 0 \\ 1.5 & 0 & 0 & 0 & 1 \\ 3 & 3 & 4.5 & 2 & 2\end{array}\right)\left(\begin{array}{c}0.5 \\ 0.5 \\ 0 \\ 0 \\ 0\end{array}\right) \quad \begin{array}{r}Z_{2}=1 ; Z_{3}=0.75 ; \\ Z_{4}=0.75 ; Z_{5}=3\end{array}$

At Run Order 2;

$\left(\begin{array}{l}Z_{1} \\ Z_{2} \\ Z_{3} \\ Z_{4} \\ Z_{5}\end{array}\right)=\left(\begin{array}{ccccc}0.6 & 0.5 & 0.65 & 0.4 & 0.45 \\ 1 & 1 & 1 & 1 & 1 \\ 0 & 1.5 & 2.5 & 1 & 0 \\ 1.5 & 0 & 0 & 0 & 1 \\ 3 & 3 & 4.5 & 2 & 2\end{array}\right)\left(\begin{array}{c}0.5 \\ 0 \\ 0 \\ 0.5 \\ 0\end{array}\right) \quad \begin{array}{r}Z_{1}=0.5 ; Z_{2}=1 ; \\ Z_{3}=0.5 ; Z_{4}=0.75 ; \\ Z_{5}=2.5\end{array}$

This procedure was carried out for the 27 run orders and the results are presented in Table 6 with their corresponding pseudo components.

\subsection{Sample preparation and testing}

Concrete batching was by weight for both phases of the experiments. For Phase A, the 12 different mixes described in Section 2.2 were batched. For the second phase, a total of 27 mixes were carried out corresponding to the 27 Run Orders in the design matrix in Table 6. Mixing, filling of molds, compaction and curing of concrete samples were in accordance with BS EN 12390-2 [37]. For each fresh mix in Phase B, workability was measured immediately after mixing using slump test and in accordance with BS EN 12350-2 [38]. Two slump tests were carried out for each mix. Three $100 \mathrm{~mm}$ $\times 100 \mathrm{~mm} \times 100 \mathrm{~mm}$ concrete cube samples were prepared for each mix (in both phases) and cured by immersion in water for 28 days. Compressive strength tests were carried out on the $28^{\text {th }}$ day for each concrete cube sample using a compression testing machine conforming to BS EN 12390-4 [39] and having a test range of $0-2000 \mathrm{kN}$. For each test, maximum load at failure was recorded and compressive strength was calculated by diving the failure load by the cross-sectional area of the sample. Three samples were tested for each mix and the average strength is reported in Fig. 2 and Table 7. 


\begin{tabular}{|c|c|c|c|c|c|c|c|c|c|c|c|}
\hline \multirow[b]{2}{*}{$\begin{array}{l}\text { Run } \\
\text { Order }\end{array}$} & \multicolumn{5}{|c|}{ Pseudo Components } & \multicolumn{5}{|c|}{ Components in Real Ratios } & \multirow{2}{*}{$\begin{array}{c}\% \\
\text { Replacemen } \\
\text { Of sand with } \\
\text { CRT }\end{array}$} \\
\hline & $x_{1}$ & $x_{2}$ & $x_{3}$ & $X_{4}$ & $X_{5}$ & $\begin{array}{c}Z_{1} \\
\text { Water }\end{array}$ & $\begin{array}{c}z_{2} \\
\text { Cement }\end{array}$ & $\begin{array}{c}Z_{3} \\
\text { Sand }\end{array}$ & $\begin{array}{c}Z_{4} \\
\text { CRT }\end{array}$ & $\begin{array}{l}Z_{5} \\
C A\end{array}$ & \\
\hline 1 & 0.5 & 0.5 & 0 & 0 & 0 & 0.55 & 1 & 0.75 & 0.75 & 3 & 50.0 \\
\hline 2 & 0.5 & 0 & 0 & 0.5 & 0 & 0.5 & 1 & 0.5 & 0.75 & 2.5 & 60.0 \\
\hline 3 & 0 & 1 & 0 & 0 & 0 & 0.5 & 1 & 1.5 & 0 & 3 & 0.0 \\
\hline 4 & 0 & 1 & 0 & 0 & 0 & 0.5 & 1 & 1.5 & 0 & 3 & 0.0 \\
\hline 5 & 0.5 & 0 & 0.5 & 0 & 0 & 0.625 & 1 & 1.25 & 0.75 & 3.75 & 37.5 \\
\hline 6 & 0 & 0 & 0 & 1 & 0 & 0.4 & 1 & 1 & 0 & 2 & 0.0 \\
\hline 7 & 0 & 0.5 & 0 & 0.5 & 0 & 0.45 & 1 & 1.25 & 0 & 2.5 & 0.0 \\
\hline 8 & 0 & 0 & 0 & 0 & 1 & 0.45 & 1 & 0 & 1 & 2 & 100.0 \\
\hline 9 & 0.1 & 0.6 & 0.1 & 0.1 & 0.1 & 0.51 & 1 & 1.25 & 0.25 & 2.95 & 16.7 \\
\hline 10 & 1 & 0 & 0 & 0 & 0 & 0.6 & 1 & 0 & 1.5 & 3 & 100.0 \\
\hline 11 & 0 & 0 & 1 & 0 & 0 & 0.65 & 1 & 2.5 & 0 & 5 & 0.0 \\
\hline 12 & 0 & 0 & 0 & 1 & 0 & 0.4 & 1 & 1 & 0 & 2 & 0.0 \\
\hline 13 & 0 & 0 & 0 & 0 & 1 & 0.45 & 1 & 0 & 1 & 2 & 100.0 \\
\hline 14 & 0.5 & 0 & 0 & 0 & 0.5 & 0.525 & 1 & 0 & 1.25 & 2.5 & 100.0 \\
\hline 15 & 0.1 & 0.1 & 0.6 & 0.1 & 0.1 & 0.585 & 1 & 1.75 & 0.25 & 3.7 & 12.5 \\
\hline 16 & 0.1 & 0.1 & 0.1 & 0.1 & 0.6 & 0.485 & 1 & 0.5 & 0.75 & 2.45 & 60.0 \\
\hline 17 & 0 & 0 & 0.5 & 0 & 0.5 & 0.55 & 1 & 1.25 & 0.5 & 3.25 & 28.6 \\
\hline 18 & 0 & 0 & 1 & 0 & 0 & 0.65 & 1 & 2.5 & 0 & 4.5 & 0.0 \\
\hline 19 & 0.2 & 0.2 & 0.2 & 0.2 & 0.2 & 0.52 & 1 & 1 & 0.5 & 2.9 & 33.3 \\
\hline 20 & 0.2 & 0.2 & 0.2 & 0.2 & 0.2 & 0.52 & 1 & 1 & 0.5 & 2.9 & 33.3 \\
\hline 21 & 0 & 0 & 0 & 0.5 & 0.5 & 0.415 & 1 & 0.5 & 0.5 & 2 & 50.0 \\
\hline 22 & 1 & 0 & 0 & 0 & 0 & 0.6 & 1 & 0 & 1.5 & 3 & 100.0 \\
\hline 23 & 0.6 & 0.1 & 0.1 & 0.1 & 0.1 & 0.56 & 1 & 0.5 & 1 & 2.95 & 66.7 \\
\hline 24 & 0.1 & 0.1 & 0.1 & 0.6 & 0.1 & 0.46 & 1 & 1 & 0.25 & 2.45 & 20.0 \\
\hline 25 & 0 & 0.5 & 0.5 & 0 & 0 & 0.575 & 1 & 2 & 0 & 3.75 & 0.0 \\
\hline 26 & 0 & 0.5 & 0 & 0 & 0.5 & 0.475 & 1 & 0.75 & 0.5 & 2.5 & 40.0 \\
\hline 27 & 0 & 0 & 0.5 & 0.5 & 0 & 0.525 & 1 & 1.75 & 0 & 3.25 & 0.0 \\
\hline
\end{tabular}

Table 6 Design matrix for Phase B showing pseudo and real components 6. táblázat A B fázis tervezési mátrixa, amely mutatja a pszeudó- és valós komponenseket egyaránt

\section{Results and discussion}

\subsection{Effect of CRT content on compressive strength - Phase A}

Result of compressive strength of the four prescribed mixes at their different levels of CRT content is presented in Fig. 2. From the result, it is obvious that incorporation of CRT significantly improves compressive strength of the resulting concrete. This is demonstrated in the four different mixes (A, B, C and D). For each of the mixes, samples with $100 \%$ CRT content performed best in terms of compressive strength followed by those with $50 \%$ CRT content, while samples with no CRT content performed least. This is similar to results of earlier studies with ceramic tiles waste aggregate $[10,11]$ and those with other ceramic waste aggregates $[14,18]$, although a few researchers have reported that replacement of conventional fine aggregate with ceramic waste aggregate does not produce any significant improvement in compressive strength of the resulting concrete [24, 25].

\subsection{Mathematical modelling - Phase B}

\subsubsection{Experimental responses for compressive strength}

Table 7 presents the average characteristic compressive strength of concrete for the 27 runs. These values define the maximum and minimum obtainable compressive strength response within the factor space of the simplex. The results also confirm that for any given mix, replacing river sand with CRT produces better compressive strength. This could be seen by comparing results at Vertex $\mathrm{X}_{4}$ (Run Orders 6 and 12) with those at Vertex $X_{5}$ (Run Orders 8 and 13). With the same mix ratio of 1:1:2 (cement: fine aggregate: Coarse aggregate), although the latter has a higher water/cement ratio than the former; its compressive strength was far higher than that of the former because CRT was used as $100 \%$ fine aggregate in the latter mix.

\subsubsection{Experimental responses for slump}

Workability of concrete mix for this work was measured in terms of slump height and the average results for each of the 27 runs are presented in Table 7 . Slump values range from $5 \mathrm{~mm}$ to $82.5 \mathrm{~mm}$ representing very low to very high slump according to Neville [6]. A close look at the slump values shows that mixes with CRT content have reduced slump heights compared to those without CRT. This has also been the trend in other reported researches $[13,14,21,24]$ and is linked to the high porosity and water absorption of ceramic waste aggregates [13]. The fact that ceramic waste aggregates are usually roughed-textured and angular in shape also results in increased friction which reduces workability. 


\begin{tabular}{|c|c|c|c|c|c|c|c|c|}
\hline \multirow{3}{*}{$\begin{array}{l}\text { Run } \\
\text { Order }\end{array}$} & \multicolumn{5}{|c|}{ Real Component Ratios } & \multirow{2}{*}{ Slump } & \multirow{2}{*}{$f_{c, 28}$} & \multirow{2}{*}{ Cost $/ m^{3}$} \\
\hline & $Z_{1}$ & $Z_{2}$ & $\mathbf{Z}_{3}$ & $\mathbf{Z}_{4}$ & $Z_{5}$ & & & \\
\hline & Water & Cement & Sand & CRT & CA & $(\mathrm{mm})$ & $\left(\mathrm{N} / \mathrm{mm}^{2}\right)$ & (USD) \\
\hline 1 & 0.55 & 1 & 0.75 & 0.75 & 3 & 40.0 & 33.844 & 80.343 \\
\hline 2 & 0.5 & 1 & 0.5 & 0.75 & 2.5 & 45.0 & 31.061 & 82.716 \\
\hline 3 & 0.5 & 1 & 1.5 & 0 & 3 & 60.0 & 28.997 & 73.146 \\
\hline 4 & 0.5 & 1 & 1.5 & 0 & 3 & 60.0 & 27.375 & 76.863 \\
\hline 5 & 0.625 & 1 & 1.25 & 0.75 & 3.75 & 47.5 & 23.766 & 71.816 \\
\hline 6 & 0.4 & 1 & 1 & 0 & 2 & 75.0 & 33.988 & 93.020 \\
\hline 7 & 0.45 & 1 & 1.25 & 0 & 2.5 & 47.5 & 28.374 & 84.031 \\
\hline 8 & 0.45 & 1 & 0 & 1 & 2 & 17.5 & 44.635 & 98.311 \\
\hline 9 & 0.51 & 1 & 1.25 & 0.25 & 2.95 & 47.5 & 27.294 & 77.835 \\
\hline 10 & 0.6 & 1 & 0 & 1.5 & 3 & 5.0 & 37.064 & 86.901 \\
\hline 11 & 0.65 & 1 & 2.5 & 0 & 4.5 & 15.0 & 21.795 & 61.438 \\
\hline 12 & 0.4 & 1 & 1 & 0 & 2 & 82.5 & 36.553 & 91.269 \\
\hline 13 & 0.45 & 1 & 0 & 1 & 2 & 10.0 & 39.947 & 98.630 \\
\hline 14 & 0.525 & 1 & 0 & 1.25 & 2.5 & 10.0 & 39.138 & 90.461 \\
\hline 15 & 0.585 & 1 & 1.75 & 0.25 & 3.7 & 22.5 & 25.427 & 69.030 \\
\hline 16 & 0.485 & 1 & 0.5 & 0.75 & 2.45 & 10.0 & 34.644 & 87.770 \\
\hline 17 & 0.55 & 1 & 1.25 & 0.5 & 3.25 & 15.0 & 25.197 & 74.589 \\
\hline 18 & 0.65 & 1 & 2.5 & 0 & 4.5 & 20.0 & 19.113 & 60.397 \\
\hline 19 & 0.52 & 1 & 1 & 0.5 & 2.9 & 25.0 & 27.549 & 78.195 \\
\hline 20 & 0.52 & 1 & 1 & 0.5 & 2.9 & 35.0 & 29.245 & 78.848 \\
\hline 21 & 0.425 & 1 & 0.5 & 0.5 & 2 & 5.0 & 40.417 & 96.868 \\
\hline 22 & 0.6 & 1 & 0 & 1.5 & 3 & 5.0 & 33.808 & 82.051 \\
\hline 23 & 0.56 & 1 & 0.5 & 1 & 2.95 & 15.0 & 30.511 & 82.880 \\
\hline 24 & 0.46 & 1 & 1 & 0.25 & 2.45 & 52.5 & 31.286 & 85.390 \\
\hline 25 & 0.575 & 1 & 2 & 0 & 3.75 & 10.0 & 23.872 & 67.693 \\
\hline 26 & 0.475 & 1 & 0.75 & 0.5 & 2.5 & 40.0 & 33.977 & 86.024 \\
\hline 27 & 0.525 & 1 & 1.75 & 0 & 3.25 & 70.0 & 26.891 & 72.030 \\
\hline
\end{tabular}

Table 7 Compressive strength and slump tests results including costs of materials per $\mathrm{m}^{3}$ of concrete

7. táblázat Nyomószilárdsági és roskadási vizsgálatok eredményei, valamint az anyagköltségek (egy $\mathrm{m}^{3}$ betonhoz)

\subsubsection{Cost estimate model data}

The cost of material required to produce $1 \mathrm{~m}^{3}$ of each of the mixes is also presented in Table 7. These values were obtained by adding up the products of the quantities of each constituent in a cubic meter of the mix and their respective unit price. The unit prices of the concrete components at the current rate are given in Table 8 . These prices are only the cost of materials and exclude cost of labour and equipment for mixing.

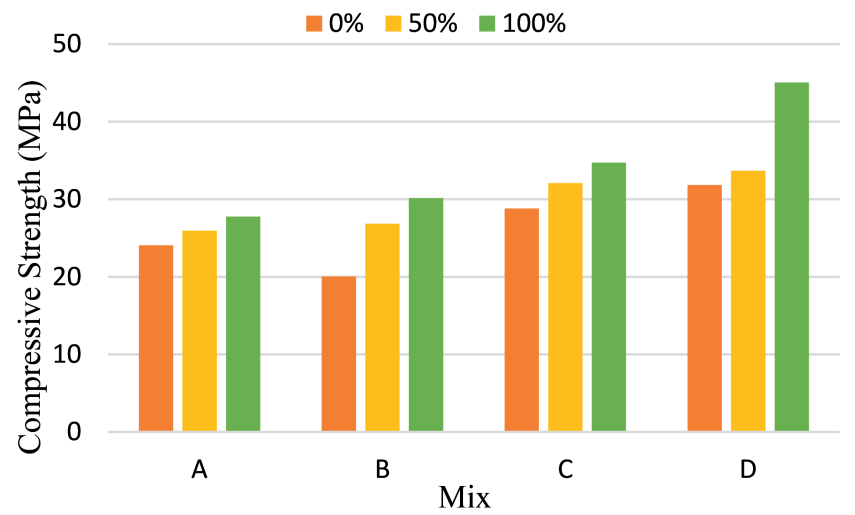

Fig. 2 Compressive strength of mix $A, B, C$ and $D$ at different percentage of CRT content 2. ábra $A z A, B, C$ és D keverék nyomószilárdsága a CRT-tartalom különböző százalékánál

\begin{tabular}{cccccc} 
Component & Water & Cement & Sand & CRT & CA \\
\hline Cost per kg (USD) & 0.001 & 0.120 & 0.005 & 0.025 & 0.016
\end{tabular}

Table 8 Cost of concrete components per $\mathrm{kg}$ 8. táblázat Beton összetevők költsége kilogrammonként

\subsubsection{Model formulation and validation}

Calibration and validation of Scheffe's augmented simplex lattice models were carried out using the respective experimental data in Table 7 with the aid of a commercial software, Minitab 16. The models were in pseudo components.

\subsubsection{Model equation for compressive strength}

Scheffe's second degree polynomial was fitted to the compressive strength data in Table 7 based on Eq. (13). To avoid overfitting the model, backward elimination procedure of stepwise regression was used. As such, insignificant terms in the model were eliminated and the resulting number of terms were less than 15 as it should be based on Eq. (6) and (13). Table 9 shows estimated model coefficients for compressive strength model with the associated statistics at 95\% confidence level, while Table 10 presents results of analysis of variance (ANOVA) and Fig. 3 is the normal probability plot of the model residuals. From the ANOVA 
table, it could be seen that both linear and quadratic sources are significant since each has a p-value less than 0.05 . However, it has been a standard practice to select the highest degree model as long as it is significant $[26,27]$. Hence, quadratic model being of higher degree was selected. Thus, if the five vertices of the designed $\{5,2\}$ simplex lattice are represented in pseudo form as $X_{1}, X_{2}, X_{3}, X_{4}$ and $X_{5}$ respectively, then compressive strength model equation based on $E q$. (13) is presented as:

$f_{c, 28}=35.71 X_{1}+27.95 X_{2}+20.42 X_{3}+35.46 X_{4}+42.13 X_{5}$

$$
-17.54 X_{1} X_{3}-20.02 X_{1} X_{4}-15.60 X_{2} X_{4}-24.45 X_{3} X_{5}
$$

\begin{tabular}{|c|c|c|c|c|}
\hline Term & Coef & SE Coef & $\mathbf{T}$ & $\mathbf{P}$ \\
\hline X1 & 35.71 & 0.9727 & * & * \\
\hline $\mathrm{X} 2$ & 27.95 & 0.9170 & * & * \\
\hline X3 & 20.42 & 0.9739 & * & * \\
\hline X4 & 35.46 & 0.9739 & * & * \\
\hline X5 & 42.13 & 0.9170 & * & * \\
\hline $\mathrm{X} 1 * \mathrm{X} 3$ & -17.54 & 6.6288 & -2.65 & 0.016 \\
\hline $\mathrm{X} 1 * \mathrm{X} 4$ & -20.02 & 6.6288 & -3.02 & 0.007 \\
\hline$X 2 * \times 4$ & -15.60 & 6.6371 & -2.35 & 0.030 \\
\hline$x 3 * x 5$ & -24.45 & 6.6371 & -3.68 & 0.002 \\
\hline \multicolumn{3}{|c|}{$S=1.55976$} & \multicolumn{2}{|c|}{$\mathrm{R}-\mathrm{Sq}=95.62 \%$} \\
\hline
\end{tabular}

Legend: Coef = Coefficients of Terms; SE Coef = Standard Error;

$T=$ t-test value; $P=$-value $S=$ Variance;

Table 9 Estimated regression coefficients for compressive strength model

9. táblázat Becsült regressziós együtthatók a nyomószilárdság modelljéhez

\section{Validation and test of adequacy:}

Normal probability plot in Fig. 3 shows a close distribution of the model residuals along a reference line. The plot has a p-value of 0.72 (which is greater than 0.05 ). Hence, the null hypothesis which states that the data follow a normal distribution - cannot be rejected. This indicates that the residuals of the model follow a normal distribution and justifies the use of ANOVA. The analysis of variance table in Table 10 shows an insignificant lackof-fit with a p-value of 0.945 (>0.05). These and other statistical values in Table 9, like r-squared value of 95.62\%, adjusted r-squared of $93.67 \%$ and predicted r-squared of $87.31 \%$ confirm the adequacy of $E q$. (20) for predicting $28^{\text {th }}$ day compressive strength of recycled ceramics tile waste concrete.

\begin{tabular}{lcccccc}
\multicolumn{1}{c}{ Source } & DF & Seq SS & Adj SS & Adj MS & F & P \\
Regression & 8 & 955.56 & 955.56 & 119.445 & 49.10 & 0.000 \\
\hline Linear & 4 & 866.05 & 793.13 & 198.282 & 81.50 & 0.000 \\
\hline Quadratic & 4 & 89.51 & 89.51 & 22.378 & 9.20 & 0.000 \\
\hline X1*X3 & 1 & 16.02 & 17.03 & 17.034 & 7.00 & 0.016 \\
\hline $\mathbf{X 1 * X 4}$ & 1 & 24.29 & 22.19 & 22.192 & 9.12 & 0.007 \\
\hline X2*X4 & 1 & 16.18 & 13.44 & 13.443 & 5.53 & 0.030 \\
\hline X3*X5 & 1 & 33.02 & 33.02 & 33.016 & 13.57 & 0.002 \\
\hline Residual Error & 18 & 43.79 & 43.79 & 2.433 & & \\
\hline Lack-of-Fit & 12 & 17.86 & 17.86 & 1.488 & 0.34 & 0.945 \\
\hline Pure Error & 6 & 25.93 & 25.93 & 4.322 & & \\
\hline Total & 26 & 999.35 & & & &
\end{tabular}

Legend: $D F=$ Degree of Freedom; Seq SS = Sequential Sum of Squares; $F=$ F-value Adj SS = Adjusted Sum of Squares; Adj MS = Adjusted Mean Squares,

Table 10 Analysis of variance for compressive strength model

10. táblázat Variancia-elemzés a nyomószilárdság modelljéhez

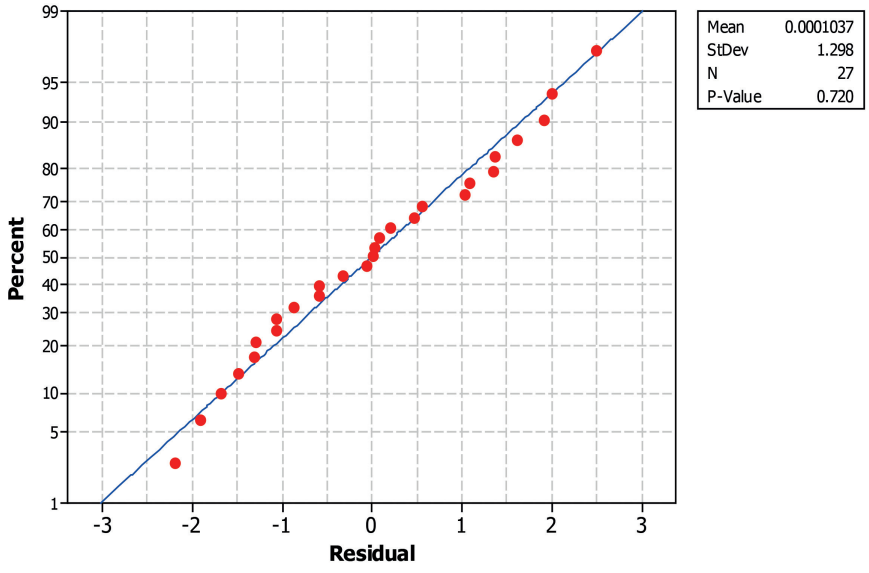

Fig. 3 Normal probability plot for compressive strength model residuals 3. ábra Normál valószínüségi diagram a nyomószilárdsági modell maradékaihoz

\subsubsection{Model equation for slump and cost}

Scheffe's augmented simplex lattice models for slump height and cost, based on Eq. (13) were fitted to the respective data in Table 7. Cost estimation is usually modelled linearly by summation of cost of concrete components [28] but this was not possible with this work since the independent variables were not concrete components in proportions, rather pseudo components of the simplex. Procedures for model calibration and validation were the same as that of compressive strength model described in 3.2.4.1. Estimated regression coefficients and analysis of variance results for both models are presented in Tables 11 to 14 while normal probability plots of model residuals are presented in Fig. 4 and Fig. 5. Using the respective model coefficients from Tables 11 and 13, Scheffe's second degree polynomials for slump and cost are presented in Eq. (21) and (22) respectively.

$$
\begin{aligned}
\text { slump }= & 5.3 X_{1}+63.3 X_{2}+16.5 X_{3}+79.8 X_{4}+13.1 X_{5}+131.9 X_{1} X_{3} \\
& -117.8 X_{2} X_{3}-85.1 X_{2} X_{4}+85.1 X_{3} X_{4}-166.1 X_{4} X_{5} \\
\cos t= & 35168 X_{1}+31210 X_{2}+25305 X_{3}+38584 X_{4}+40934 X_{5} \\
& -9461 X_{1} X_{4}-7926 X_{3} X_{4}-8848 X_{3} X_{5}
\end{aligned}
$$

\begin{tabular}{lcccc} 
Term & Coef & SE Coef & T & P \\
$\mathbf{X 1}$ & 5.3 & 3.207 & $*$ & $*$ \\
\hline $\mathbf{X 2}$ & 63.3 & 3.402 & $*$ & $*$ \\
\hline $\mathbf{X 3}$ & 16.5 & 3.603 & $*$ & $*$ \\
\hline $\mathbf{X} 4$ & 79.8 & 3.603 & $*$ & $*$ \\
\hline $\mathbf{X 5}$ & 13.1 & 3.207 & $*$ & $*$ \\
\hline $\mathbf{X 1 * X 3}$ & 131.9 & 23.223 & 5.68 & 0.000 \\
\hline $\mathbf{X 2 * X 3}$ & -117.8 & 23.196 & -5.08 & 0.000 \\
\hline $\mathbf{X 2 * X 4}$ & -85.1 & 23.196 & -3.67 & 0.002 \\
\hline $\mathbf{X 3 * X 4}$ & 85.1 & 23.169 & 3.67 & 0.002 \\
\hline $\mathbf{X 4 * X 5}$ & -166.1 & 23.223 & -7.15 & 0.000 \\
\hline $\mathbf{S}=\mathbf{5 . 4 5 5 0 2}$ & & & $\mathrm{R}-\mathrm{Sq}=96.47 \%$ \\
$\mathbf{R - S q}(\mathbf{p r e d})=\mathbf{8 3 . 1 7 \%}$ & & $\mathrm{R}-\mathrm{Sq}(\mathrm{adj})=94.60 \%$
\end{tabular}

Table 11 Estimated regression coefficients for slump model 11. táblázat Becsült regressziós együtthatók a roskadás modelljéhez 


\begin{tabular}{lcccccc}
\multicolumn{1}{c}{ Source } & DF & Seq SS & Adj SS & Adj MS & F & P \\
Regression & 9 & 13815.4 & 13815.4 & 1535.05 & 51.59 & \\
\hline Linear & 4 & 9774.6 & 10581.2 & 2645.30 & 88.90 & 0.000 \\
\hline Quadratic & 5 & 4040.8 & 4040.8 & 808.17 & 27.16 & 0.000 \\
\hline $\mathbf{X 1 * X 3}$ & 1 & 784.8 & 960.7 & 960.66 & 32.28 & 0.000 \\
\hline $\mathbf{X 2 * X 3}$ & 1 & 909.1 & 768.0 & 767.98 & 25.81 & 0.000 \\
\hline $\mathbf{X 2 * X 4}$ & 1 & 373.4 & 400.2 & 400.18 & 13.45 & 0.002 \\
\hline $\mathbf{X 3 * X 4}$ & 1 & 450.8 & 401.5 & 401.51 & 13.49 & 0.002 \\
\hline $\mathbf{X 4 * X 5}$ & 1 & 1522.7 & 1522.7 & 1522.68 & 51.17 & 0.000 \\
\hline Residual Error & 17 & 505.9 & 505.9 & 29.76 & & \\
\hline Lack-of-Fit & 11 & 387.1 & 387.1 & 35.19 & 1.78 & 0.248 \\
\hline Pure Error & 6 & 118.7 & 118.7 & 19.79 & & \\
\hline Total & 26 & 14321.3 & & & &
\end{tabular}

Table 12 Analysis of variance for slump model

12. táblázat Variancia-elemzés a roskadás modelljéhez

\begin{tabular}{|c|c|c|c|c|}
\hline Term & Coef & SE Coef & $\mathbf{T}$ & $\mathbf{P}$ \\
\hline X1 & 35168 & 315.9 & * & * \\
\hline $\mathbf{X 2}$ & 31210 & 296.4 & * & * \\
\hline $\mathrm{x} 3$ & 25305 & 335.2 & * & * \\
\hline $\mathrm{X4}$ & 38584 & 335.2 & * & * \\
\hline $\mathrm{X} 5$ & 40934 & 315.9 & * & * \\
\hline $\mathrm{X} 1 * \mathrm{X} 4$ & -9461 & 2283.8 & -4.14 & 0.001 \\
\hline $\mathrm{X3} * \mathrm{X} 4$ & -7926 & 2281.3 & -3.47 & 0.003 \\
\hline$x 3 * \times 5$ & -8848 & 2283.8 & -3.87 & 0.001 \\
\hline \multicolumn{3}{|c|}{$S=537.693$} & \multicolumn{2}{|c|}{$\mathrm{R}-\mathrm{Sq}=98.86 \%$} \\
\hline
\end{tabular}

Table 13 Estimated regression coefficients for cost model

13. táblázat Becsült regressziós együtthatók a költségmodellhez

\section{Validation and test of adequacy:}

Again, normal probability plots in Fig. 4 and Fig. 5 both show close distribution of their respective model residuals along a reference line. The plots have p-values of 0.92 and 0.847 (which are both greater than 0.05 ) respectively. Hence, the null hypothesis cannot be rejected. These indicate that the residuals of both models follow a normal distribution and justifies the use of ANOVA. The analysis of variance tables in Tables 12 and 14 show insignificant lack-of-fits with p-values of 0.248 and 0.987 . These and other statistical values in Tables 12 and 14, like r-squared values of $96.47 \%$ and $98.86 \%$, adjusted r-squared of $94.6 \%$ and $98.44 \%$ and predicted $r$-squared of $83.17 \%$ and $97.29 \%$ confirm the adequacy of Eqs. (21) and (22).

\begin{tabular}{lcccccc}
\multicolumn{1}{c}{ Source } & DF & Seq SS & Adj SS & Adj MS & F & P \\
Regression & 7 & 476930824 & 476930824 & 68132975 & 235.66 & 0.000 \\
\hline Linear & 4 & 464094664 & 442322554 & 110580639 & 382.48 & 0.000 \\
\hline Quadratic & 3 & 12836160 & 12836160 & 4278720 & 14.80 & 0.000 \\
\hline $\mathbf{X 1 * X 4}$ & 1 & 5241710 & 4962268 & 4962268 & 17.16 & 0.001 \\
\hline $\mathbf{X 3 * X 4}$ & 1 & 3254759 & 3489671 & 3489671 & 12.07 & 0.003 \\
\hline $\mathbf{X 3 * X 5}$ & 1 & 4339691 & 4339691 & 4339691 & 15.01 & 0.001 \\
\hline Residual & 19 & 5493161 & 5493161 & 289114 & & \\
Error & & & & & & \\
\hline Lack-of-Fit & 13 & 1845746 & 1845746 & 141980 & 0.23 & 0.987 \\
\hline Pure Error & 6 & 3647415 & 3647415 & 607903 & & \\
\hline Total & 26 & 482423985 & & & &
\end{tabular}

Table 14 Analysis of variance for cost model 14. táblázat Varianciaanalízis a költségmodellhez

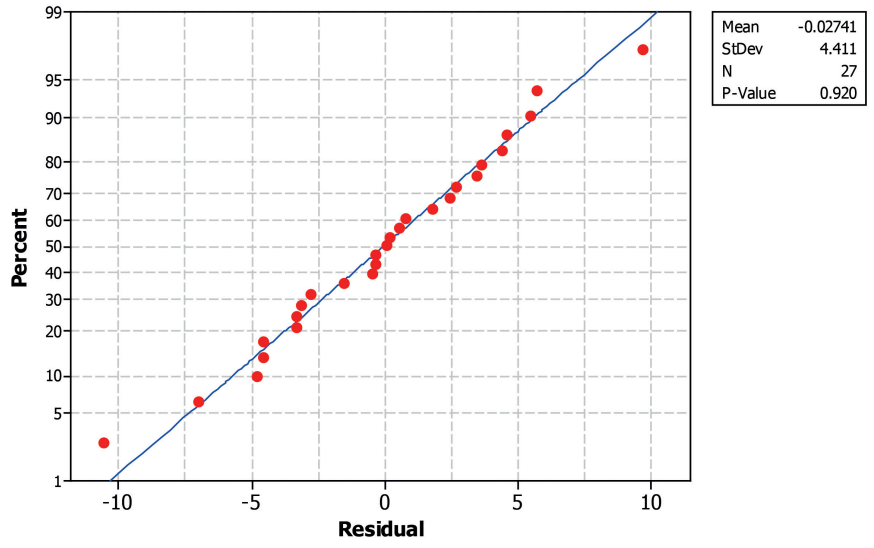

Fig. 4 Normal probability plot for slump model residuals

4. ábra Normál valószínüségi diagram a roskadás modelljének maradékaihoz

\subsection{Sample optimization}

RSM combines mathematical and statistical methods of experiment design, regression analysis and optimization to provide approaches to mixture optimization. Hence, once the required responses have been modeled, optimization can easily be carried out for any set of desired criteria. In this study, having formulated model equations for compressive strength, slump height and cost estimate, sample optimization of recycled ceramic waste concrete mix was carried out with the aid of Altair Hyperstudy software using three different techniques. The techniques were: Adaptive Response Surface Method (ARSM), Global Response Search Method (GRSM) and Sequential Quadratic Programming (SQP). The main objective of the optimization was to generate the most cost-effective mix designs with compressive strength of at least 35 $\mathrm{MPa}$ and minimum slump of $25 \mathrm{~mm}$.

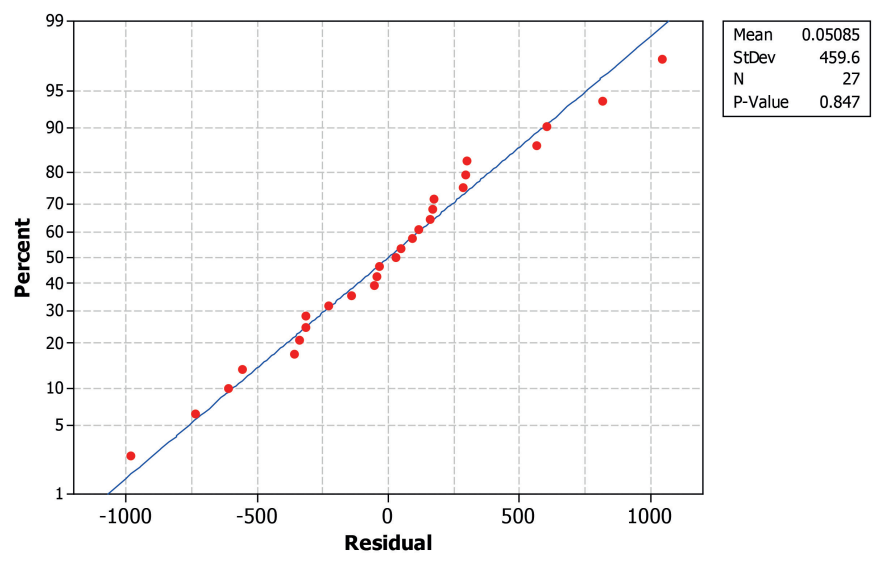

Fig. 5 Normal probability plot for cost model residuals

5. ábra Normál valószínúségi diagram a költségmodell maradékaihoz

\subsubsection{Formulation of optimization problem}

Design variables for this optimization were the five concrete components in pseudo form denoted as $X_{1}, X_{2}, X_{3}, X_{4}$ and $X_{5}$ while Eq. (3) was used as side constraints for each of the variables. The initial value for the variables was 0.2 representing the centroid of the simplex. Since the objective was to minimize cost, the cost model in Eq. (22) was used as objective function. Design constraints were formulated as below based on Eqs. (2), (20) and (21): 
$X_{1}+X_{2}+X_{3}+X_{4}+X_{5}=1.00$

$5.3 X_{1}+63.3 X_{2}+16.5 X_{3}+79.8 X_{4}+13.1 X_{5}+131.9 X_{1} X_{3}$

$-117.8 X_{2} X_{3}-85.1 X_{2} X_{4}+85.1 X_{3} X_{4}-166.1 X_{4} X_{5} \geq 25.00$

$35.71 X_{1}+27.95 X_{2}+20.42 X_{3}+35.46 X_{4}+42.13 X_{5}$

$-17.54 X_{1} X_{3}-20.02 X_{1} X_{4}-15.60 X_{2} X_{4}-24.45 X_{3} X_{5} \geq 35.00$

\subsubsection{Optimization results}

Optimization results for the three techniques are presented in Table 15. Outputs from Hyperstudy were in pseudo components and were therefore transformed to real component ratios using Eq. (19). The three techniques all started their search from the centroid of the simplex using iteration approach. Surprisingly, they arrived at their optimum at different points in the simplex leading to different results. However, GRSM seems to be the most suitable for this optimization because it achieved the most economical mix of $\$ 92.77$ per $\mathrm{m}^{3}$, while still maintaining the required compressive strength and slump height.

\subsection{Discussion of results}

Results from this work, especially that of Phase A as presented in Fig. 2, has confirmed that incorporation of CRT as fine aggregate in concrete increases its compressive strength. This increase is directly proportional to the percentage replacement of sand with CRT. This is not surprising because similar results have been reported elsewhere $[10,11,14,18]$ although some with the use of other ceramic aggregates other than CRT. Torkittikul and Chaipanich had earlier reported $50 \%$ as the optimum replacement level and discouraged higher replacement level [14]. However, it should be noted that their decline in compressive strength at replacement level higher than $50 \%$ was due to reduced workability associated with the increased ceramic aggregate content. Replacement of conventional fine aggregate with ceramic aggregate can therefore be up to $100 \%$ depending on the workability of a mix. Most ceramic aggregates are porous and possess higher water absorption property than sand $[10,13,14,24]$. This means that during mixing, ceramic aggregates absorb more water than sand, thereby reducing the actual quantity of water used for lubricating the mix constituents. Hence, in designing such mix, provision should be made for this absorbed water.

Using Scheffe's simplex theory, polynomial models have been developed for compressive strength, workability and cost of CRT aggregate concrete. The use of stepwise regression during modelling procedures ensured that all insignificant variables were removed from the model predictors to avoid overfitting.
This practice paid off and its benefits are demonstrated in the model statistics shown in Tables $9-14$ and Figs. 3 - 5. Tables 9,11 and 13 show that only significant model terms at $95 \%$ confidence level (terms with p-values less than 0.05) were selected as predictors for each of the formulated models. The high $r$-squared, adjusted $r$-squared and predictive $r$-squared values reflects the high quality of the models. While $r$-squared and adjusted r-squared values show how well the models fit their respective data, the high predictive $r$-squared values indicate how well the formulated models can predict new responses outside the design points. The three models show insignificant lack-of-fit as indicated in ANOVA tables in Tables 10, 12 and 14 .

Maximum predictable response from the compressive strength model was $42.13 \mathrm{MPa}$ existing at vertex $\mathrm{X}_{5}$ of the simplex and corresponding to mix ratio of 0.45:1:0:1:2 for water, cement, sand, CRT and CA. On the other hand, the lowest predictable compressive strength was found to be $20.34 \mathrm{MPa}$ existing very close to Vertex $\mathrm{X}_{3}$ and corresponding to mix ratio of $0.64: 1: 2.35: 0.06 ; 4.35$. This means that the compressive strength model can be used to predict concrete grades C16/20 to C30/37 according to BS EN 206 [40] and this falls within the range of commonly used concrete grades especially for reinforced concrete.

\section{Conclusions}

In this study, effect of CRT fine aggregate content on compressive strength of concrete have been studied. From the experimental investigations, incorporation of this recycled waste aggregate increases compressive strength of concrete and the increase is directly proportional to the percentage replacement of sand with CRT. Authors therefore recommends up to $100 \%$ replacement of conventional fine aggregate with ceramic aggregate depending on the workability of the mix. Scheffe's second degree polynomial models were also formulated for compressive strength, slump height and cost of concrete incorporating CRT as fine aggregate. Stepwise regression was used during model fitting and selections. The models were validated using analysis of variance and normal probability plots of model residuals and their adequacies were confirmed. Maximum and minimum predictable compressive strengths were $42.13 \mathrm{MPa}$ and $20.34 \mathrm{MPa}$ respectively indicating that the compressive strength model can be used to predict concrete grades $\mathrm{C} 16 / 20$ to $\mathrm{C} 30 / 37$ according to $\mathrm{BS} \mathrm{EN}$ 206. Optimization was carried out using three optimization techniques (ARSM, GRSM and SQP) to obtain the most economical mix with a compressive strength of at least $35 \mathrm{MPa}$

\begin{tabular}{lcccccccccccccc}
$\begin{array}{c}\text { Optimization } \\
\text { technique }\end{array}$ & $\mathbf{X}_{1}$ & $\mathbf{X}_{2}$ & $\mathbf{X}_{3}$ & $\mathbf{X}_{4}$ & $\mathbf{X}_{5}$ & $\mathbf{Z}_{1}$ & $\mathbf{Z}_{2}$ & $\mathbf{Z}_{3}$ & $\mathbf{Z}_{4}$ & $\mathbf{Z}_{5}$ & $\mathbf{f}_{c, 28}$ & $\begin{array}{c}\text { Slump } \\
\text { (MPa) }\end{array}$ & $\begin{array}{c}\text { Rest } \\
\text { (mm) }\end{array}$ & (USD) \\
ARSM & 0.123 & 0.000 & 0.037 & 0.559 & 0.281 & 0.448 & 1.000 & 0.652 & 0.466 & 2.216 & 35.10 & 25.83 & 90.379 \\
\hline GRSM & 0.437 & 0.305 & 0.000 & 0.000 & 0.258 & 0.531 & 1.000 & 0.458 & 0.914 & 2.742 & 35.00 & 25.00 & 84.710 \\
\hline SQP & 0.000 & 0.000 & 0.116 & 0.549 & 0.335 & 0.446 & 1.000 & 0.839 & 0.335 & 2.290 & 35.00 & 25.00 & 89.598
\end{tabular}

Table 15 Optimum mix in pseudo and real components and their corresponding responses

15. táblázat A pszeudó- és valós komponensek optimális keveréke és az azokhoz tartozó mechanikai tulajdonságok és költségek 
and slump height of at least $25 \mathrm{~mm}$. From optimization results, the three techniques arrived at optimum at different points in the simplex leading to different results. However, GRSM proved to be the most suitable technique for this purpose. With the model equations, similar optimization can be carried out for any desired response within the simplex.

\section{Acknowledgement}

Authors acknowledge the financial support of Tertiary Education Trust Fund (TETFund) Nigeria for the PhD studies of Edidiong E. Ambrose.

\section{Conflict of interests}

Authors declare that there is no conflict of interests in this research work.

\section{References}

[1] Ikponmwosa, E. E. - Ehikhuenmen, S. O. (2017): The effect of ceramic waste as coarse aggregate on strength properties of concrete, Nigerian Journal of Technology. Vol. 36, No. 3, pp.691-696.

https://dx.doi.org/10.4314/njt.v36i3.5.

[2] Tahar, Z. - Benabed, B. - Kadri, E. H. - Ngo, T. - Bouvet, A. (2020): Rheology and strength of concrete made with recycled concrete aggregate as replacement of natural aggregates, Epitoanyag Journal of Silicate Based and Composite Materials, Vol. 72, No. 2, pp.48-58. https://doi.org/10.14382/epitonyag.jsbcm.2020.8.

[3] Domone, P. - Illston, J. (2010): Construction materials - the nature and behaviour, $4^{\text {th }}$ edn, CRC Press, New York.

[4] Gartner E. (2004): Industrial interesting approaches to low $\mathrm{CO}_{2}$, Cement and Concrete Research, Vol. 34, No. 9, pp.1489-1498.

https://doi.org/10.1016/j.cemconres2004.01.021.

[5] Allahverdi, A. - Mahinroosta, M. - Pilehvar, S. (2017) A temperatureage model for prediction of compressive strength of chemically activated high phosphorus slag content cement. International Journal of Civil Engineering, Vol. 15, No. 5, pp. 839-847. https://doi.org/10.1007/s40999-017-0196-5

[6] Neville, A. M. (2011): Properties of concrete, $5^{\text {th }}$ edn, Pearson Education, London.

[7] Kannan, D. M. - Aboubakr, S. H. - El-Dieb, A. S. - Taha, M. M. (2017): High performance concrete incorporating ceramic wastes powder as large partial replacement of Portland cement. Construction and Building Materials, Vol. 144, pp.35-41. https://doi.org/10.1016/j.conbuildmat.2017.03.115.

[8] Tang, W. C. - Lo, Y. - Nadeem, A. (2008): Mechanical and dryness shrinkage properties of structural-graded polystyrene aggregate concrete, Cement and Concrete Composite, Vol. 30, No. 5, pp.403-409. https://dx.doi.org/10.4314/j.cemconcomp.2008.01.002.

[9] Ambrose, E. E. - Ekpo, D. U. - Umoren, I. M. - Ekwere, U. S. (2018): Compressive strength and workability of laterized quarry sand concrete. Nigerian Journal of Technology, Vol. 36, No. 3, pp.605-610. https://dx.doi.org/10.4314/njtv37i3.7.

[10] Elci, H. (2016): Utilization of crushed floor and wall tile wastes as aggregate in concrete production. Journal of Cleaner Production, Vol. 112 pp.742-752. https://doi.org/10.1016/j.jclepro2015.07.003.

[11] Awoyera, P. O. - Ndambuki, J. M. - Akinmusuru, J. O. - Omole, O. D. (2018): Characterization of ceramic waste aggregate. HBRC Journal, Vol. 14, No. 3, pp.282-287. https://doi.org/10.1016/j.hbrcj.2016.11.003.

[12] Zimbili, O. - Salim, W. - Ndambuki, M. (2014) A review on the usage of ceramic wastes in concrete production, International Journal of Civil, Environmental, Structural, Construction and Architectural Engineering. Vol. 8, No. 1, pp.91-95.
[13] Halicka, A. - Ogrodnik, P. - Zegardlo, B. (2013): Using ceramic sanitary ware waste as concrete aggregate. Construction and Building Materials Vol. 48 pp.295-305. https://doi.org/10.1016/j.conbuildmat.2013.06.063.

[14] Torkittikul, A. - Chaipanich, A. (2010): Utilization of ceramic waste as fine aggregate within Portland cement and fly ash concrete. Cement and Concrete Composite. Vol. 32, pp.440-449. https://doi.org/10.1016/j.cemconcomp.2010.02.004.

[15] Heidari, A. - Tavakoli, D. (2013); A study of the mechanical properties of ground ceramic powder concrete incorporating nano- $\mathrm{SiO}_{2}$ particles, Construction and Building Materials Vol. 38, pp.255-264. https://doi.org/10.1016/j.conbuildmat.2012.07.110.

[16] Daniyal, M. - Ahmad, S. (2015): Application of waste ceramic tile aggregates in concrete, International Journal of Innovative Research in Science and Engineering Technology, Vol. 4, No. 12, pp.12808-12815. https://doi.org/10.15680/IJIRSET.2015.0412128.

[17] Medina, C. - Rojas, M. I. - Frias, M. (2012): Reuse of sanitary ceramic wastes as coarse aggregate in eco-efficient concretes, Cement and Concrete Composite, Vol. 34, pp.48-54.

https://doi.org/10.1016/j.cemconcomp.2011.08.015.

[18] Pacheco-Torgal, F. - Jalali, S. (2010): Reuse of ceramic wastes in concrete, Construction and Building Materials, Vol. 24, pp.832-838. https://doi.org/10.1016/j.conbuildmat.2009.10.023.

[19] Medina, C. - Frias, M. - Rojas, M. I. (2012): Microstructure and properties of recycled concrete using ceramic sanitary ware industry waste as coarse aggregate, Construction and Building Materials, Vol. 31, pp.112-118. https://doi.org/10.1016/j.conbuildmat.2011.12.075.

[20] Shruthi, H. G. - Gowtham, M. E. - Samreen, T. - Syed, R. P. (2016): Reuse of ceramic wastes as aggregate in concrete. International Research Journal of Engineering and Technology, Vol. 3, No. 7, pp.115-119.

[21] Awoyera, P. O. - Akinmusuru, J. O. - Ndumbuki, J. M. (2016): Green concrete production with ceramic wastes and laterite. Construction and Building. Materials, Vol. 117, pp.29-36. https://doi.org/10.1016/j.conbuildmat.2016.04.108.

[22] Adamson, M. - Razmjoo, A. - Poursaee, A. (2015): Durability of concrete incorporating crushed brick as coarse aggregate. Construction and Building Materials, Vol. 94, pp.426-434. https://doi.org/10.1016/j.conbuildmat.2015.07.056.

[23] Zegardlo, B. - Szelag, M. - Ogrodnik, P. (2016): Ultra-high strength concrete made with recycled aggregate from sanitary ceramic wastes - the method of production and the interfacial transition zone. Construction and Building Materials, Vol. 122, pp.736-742. https://doi.org/10.1016/j.conbuildmat.2016.06.112.

[24] Alves, A. V. - Vieira, T. F. - Brito, J. - Correia, J. R. (2014): Mechanical properties of structural concrete with fine recycled ceramic aggregate, Construction and Building Materials, Vol. 64, pp.103-113. https://doi.org/10.1016/j.conbuildmat.2014.04.037.

[25] Aliabdo, A. A. - Abd-Emoatry, A. M. - Hassan, H. H. (2014): Utilization of crushed clay brick in concrete industry. Alexandria Engineering Journal, Vol. 53, No. 1, pp.151-168. https://doi.org/10.1016/j.aej.2013.12.003.

[26] Anya, U. C. (2015): Models for predicting the structural characteristics of sand-quarry dust blocks. Ph.D Dissertation, University of Nigeria.

[27] Simon, M. J. (2003): Concrete mixture optimization using statistical methods: Final Report. Federal Highway Administration, Infrastructure Research and Development, Georgetown Pike McLean, VA, USA.

[28] DeRousseau, M. A. - Kasprzyk, J. R. - Srubar, W. V. (2018): Computational design optimization of concrete mixture: a review, Cement and Concrete Research, Vol. 109, pp.42-53.

[29] Okafor, F. O. - Oguaghamba, O. (2010): Procedures for optimization using scheffe's model, Journal of Engineering Science and Application, Vol. 7, No. 1, pp.36-46.

[30] Osadebe, N. N. - Mbajiorgu, C. C. - Nwakonobi, T. U. (2007): An optimization model development for laterized concrete mix proportioning in building constructions. Nigerian Journal of Technology, Vol. 26, No. 1. Pp.37-45.

[31] Onuamah, P. N. - Osadebe, N. N. (2015): Development of optimized strength model of lateritic hollow block with $4 \%$ mound soil inclusion, Nigerian Journal of Technology, Vol. 34, No. 1, pp.1-11. https://doi.org/10.4314/njt.v34i1.1. 
[32] Akhnazarova, S. - Kafarov, V. (1982): Experiment Optimization in Chemistry and Chemical Engineering, MIR Publishers, Moscow.

[33] Scheffe, H. (1958): Experiment with mixtures, Journal of Royal Statistics Society, Vol. 20, No. 2, pp.344-360.

https://doi.org/10.1111/j.2517-6161.1958.tb00299.x.

[34] Attah, I. C. - Etim, R. K. - George, U. A. - Bassey, O. B. (2020); Optimization of mechanical properties of rice husk ash concrete using Scheffe's theory, SN Applied Sciences, Vol. 2 p.928.

https://doi.org/10.1007/s42452-020-2727-y.

[35] Onyelowe, K. - Alaneme, G. - Igboayaka, C. - Orji, F. - Ugwuanyi, H. Van, D. B. - Van, M. N. (2019): Scheffe optimization of swelling, Califonia bearing ratio, compressive strength, and durability potentials of quarry dust stabilized soft clay soil, Material Science for Energy Technology, Vol. 2, pp.67-77. https://doi.org/10.1016/j.mset.2018.10.005.

[36] NIS 444-1 (2008): Composition, specification and conformity criteria for common cements, Standard Organization of Nigeria, Abuja.
[37] BS EN 12390-2 (2009): Testing hardened concrete - Part 2: making and curing specimens for strength tests. British Standard Institute, London.

[38] BS EN 12350-2 (2009): Testing fresh concrete - part 2: slump test. British Standard Institute, London.

[39] BS EN 12390-4 (2000): Testing hardened concrete - part 4: compressive strength - specification for testing machines. British Standard Institute, London.

[40] BS EN 206 (2013): Concrete - specification, performance, production and conformity. British Standard Institute, London.

Ref.:

Ambrose, Edidiong E. - Okafor, Fidelis O.- Onyia, Michael E. Compressive strength and Scheffe's optimization of mechanical properties of recycled ceramics tile aggregate concrete Építőanyag - Journal of Silicate Based and Composite Materials, Vol. 73, No. 3 (2021), 91-102. p. https://doi.org/10.14382/epitoanyag-jsbcm.2021.14

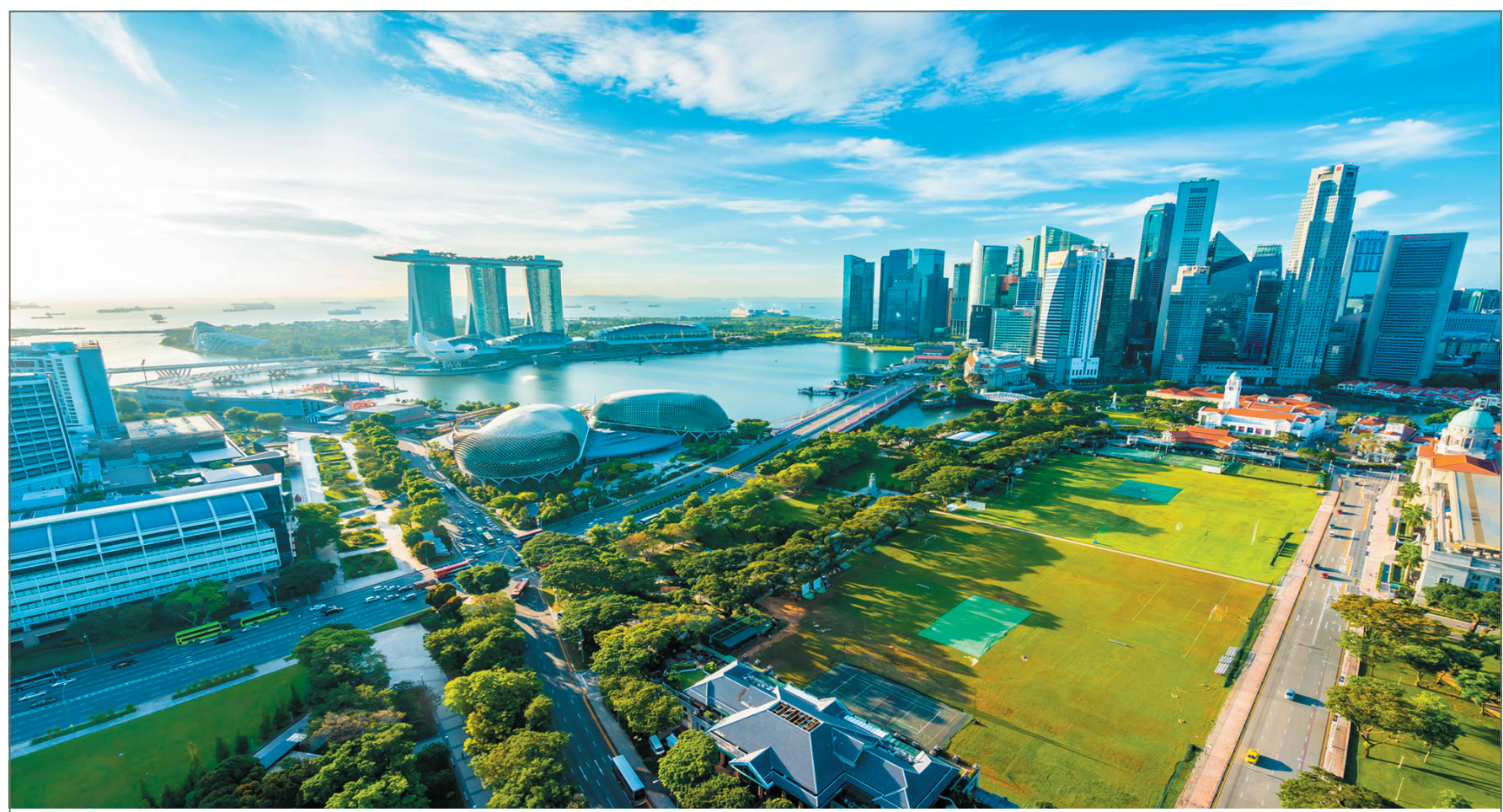

\section{ICCEN 2021}

\section{$20219^{\text {th }}$ International Conference on Civil Engineering} will be held during October 14-16, 2021 in Singapore.

ICCEN 2021 is co-sponsored by the Hong Kong Chemical, Biological \& Environmental Engineering Society (HKCBEES). It is one of the leading international conferences for presenting novel and fundamental advances in the fields of Civil Engineering. It also serves to foster communication among researchers and practitioners working in a wide variety of scientific areas with a common interest in improving Civil Engineering related techniques.

\section{www.iccen.org}

